\title{
CENTRAL $\beta$-ADRENERGIC RECEPTORS FOR BLOOD PRESSURE REGULATION IN SPONTANEOUSLY HYPERTENSIVE RATS
}

\author{
Tadatoshi NOMURA \\ Department of Pathology, Faculty of Medicine, Kyoto University. \\ Sakyo-ku, Kyoto 606, Japan
}

Accepted February 16, 1976

The role of central catecholaminergic mechanisms in blood pressure regulation has been studied in spontaneously hypertensive rats (SHR) by Yamori et al. (1-4). These studies on norepinephrine (NE) synthesizing enzymes or NE turnover of the brain $(1,2)$ and central depressor effect of $\alpha$-agonists (3-5) indicated that noradrenergic mechanisms in the central nervous system (CNS), particularly, $\alpha$-receptors act as sympatho-inhibitory or depressor mechanisms which may be inadequate in SHR (3-6) as well as in other hypertensive states. The existence of such central sympatho-inhibitory mechanisms in rats was further confirmed pharmacologically $(7-10)$ or by the induction of temporal hypertension following the destruction of central noradrenergic mechanisms (11).

On the other hand, failure of the development of renal (12), DOCA (13) or spontaneous (13) hypertension after the destruction of central catecholaminergic mechanisms indicated the possible existence of central catecholaminergic pressor mechanisms (6). The pressor effect of centrally administered $\beta$-agonist (isoproterenol, salbutamol) and its abolishment by the pretreatment of $\beta$-blocker (propranolol) were observed in conscious cats $(14,15)$. These findings suggested that central catecholaminergic pressor mechanisms might be related to $\beta$-receptors in the brain.

Therefore, effects of centrally administered $\beta$-agonists and $\beta$-blockers were observed in rats, especially in SHR, to investigate the role of central $\beta$-receptors in blood pressure regulation in hypertensive states (16). Central $\beta$-receptors were further analyzed according to $\beta_{1}$-and $\beta_{2}$-subclassifications of peripheral $\beta$-receptors (17).

Twenty-five SHR at 12 to 15 weeks of age, and with established hypertension were used with 25 age-matched normotensive Wistar-Kyoto (WK) from which the SHR had been derived. Rats were fixed on a stereotaxic apparatus without anesthesia and the following drugs dissolved in $20, \mu 1$ of physiological saline were injected mainly into the right lateral ventricle with a microsyringe (16). $\beta$-agonist, isoproterenol (Sigma); $\alpha$-and $\beta_{1}$-agonist, nordefrine (Sterling-Winthrop Research Institute); $\beta_{2}$-agonist, salbutamol (Sankyo Pharmaceutical) and orciprenaline (C.H. Boehringer-Sohn); $\beta_{1^{-}}, \beta_{2}$-blocker, propranolol (Sumitomo Chemical); $\beta_{1}$-blocker, practolol (Otsuka Pharmaceutical) and $\alpha$-blocker, phentolamine (CIBA-Geigy). Each agent was freshly dissolved in physiological saline before injection. Direct blood pressure was recorded through a transplanted catheter into the femoral artery by a polygraph (Nihon Kohden, RP-5) connected with a transducer (Toyo-Baldwin, MPU$0.5)$. All numerical data were analyzed for statistical difference by student's $t$-test. The 
intraventricular injection (i.vt.) of $\beta$-agonist, isoproterenol $(0.5-10 \mu \mathrm{g})$ decreased the blood pressure as well as $\alpha$ - and $\beta_{1}$-agonist, nordefrine $\left(1-50 / / \mathrm{g}\right.$, i.v1.), but $\beta_{2}$-agonist, salbutamol (0.5-30 $\mu \mathrm{g}$, i.vt.) and orciprenaline $(0.5-10 \mu \mathrm{g}$, i.vt.), increased the blood pressure in SHR and WK (Fig. 1.) $\beta$-blocker, propranolol (50-300 $\mu \mathrm{g}$, i.vt.), itself caused a transient rise, did not block the depressor effect of isoproterenol and nordefrine, but did block the pressor effect of orciprenaline.

The central pressor effect of salbutamol and orciprenaline or the depressor effect of nordefrine was not blocked by the pretreatment of $\beta_{1}$-blocker, practolol (100 $\mu \mathrm{g}$, i.vt.). On the other hand, the pretreatment of $\alpha$-blocker, phentolamine (100 $\mu \mathrm{g}$, i.vt.) blocked the depressor effect of isoproterenol and nordefrine. Therefore, the central depressor effect of isoproterenol and nordefrine may be mainly due to their $\alpha$-effect.

Central Responses to $\beta$-Agonists in SHR
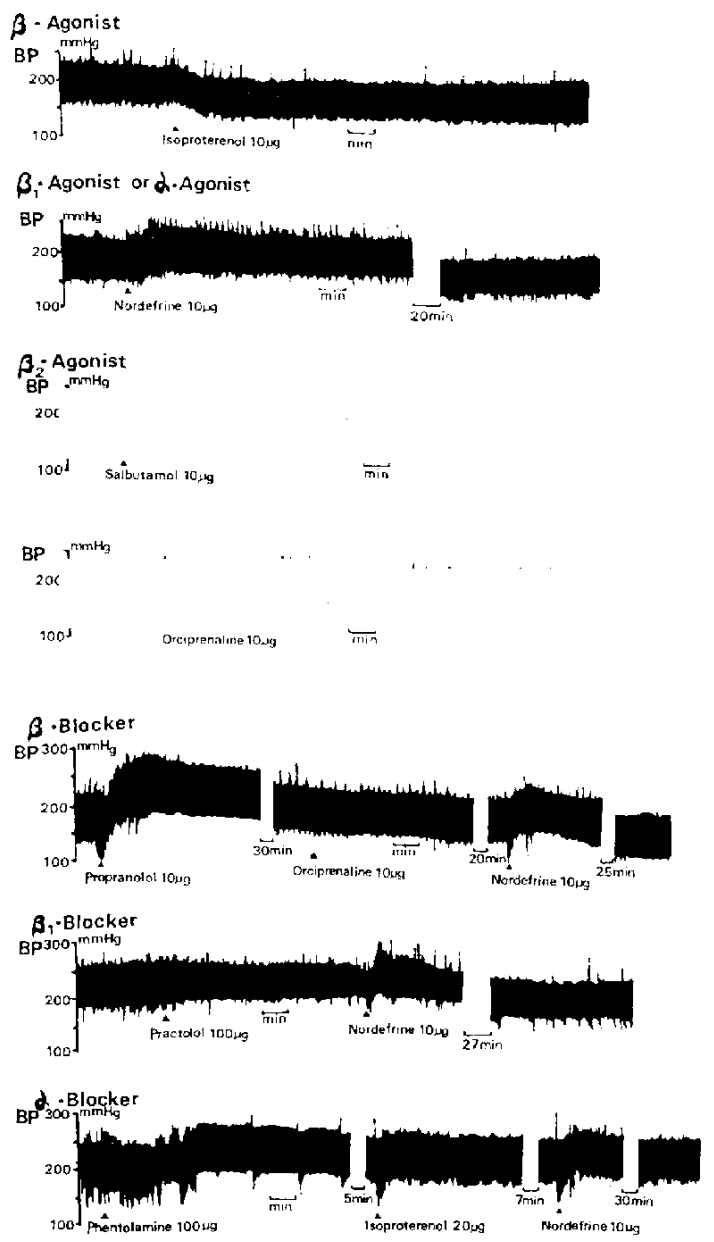

Fig. 1. Central responses to $\beta$-agonists with or without the pretreatment of $\alpha$-or 3-blocker in SHR. 
However, $\beta_{2}$-agonist such as salbutamol and orciprenaline may cause contral pressor responses through $\beta\left(\beta_{2}\right)$-receptors.

Dose-response curve showed that depressor response to nordefrine, i.e., $\alpha$-methyl norepincphrine (decarboxylated product of $\alpha$-methyl dopa) was obviously greater in SHR than in WK (Fig. 2). This finding was consistent with Yamori ct al's suggestions (3-6) that the central depressor effect of $\alpha$-methyl dopa was mediated through $\alpha$-methyl norepinephrine, and such a clear difference in dose-response curve indicated the involvement of central $a$ receptors in the hypertension of SHR. On the other hand, significantly increased central pressor response to salbutamol and orciprenaline, as shown in the dose-response curve, indicated the involvement of $\beta_{2}$-receptors in the hypertensive state.

Dose-Pesponse Curve for Centra Effect of $\beta$-Agonsts in SHR

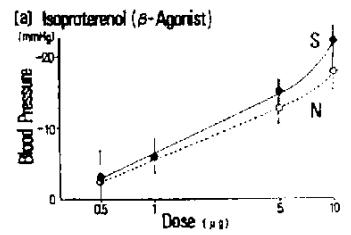

(c) Salbutemol ( $\beta_{2}$-Agonist)

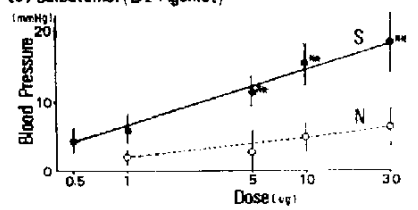

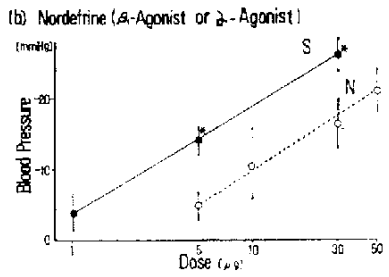

d) Onciprenaline (AsAzonist:

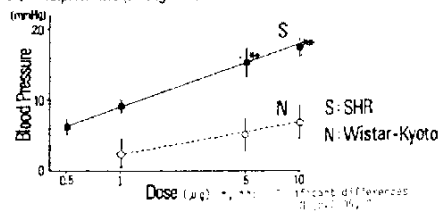

Fic. 2. Dose-response curve to isoproterenol, nordefrine, orciprenaline and salbutamol in SHR and normotensive Wistar-Kyoto.

As isoproterenol has $\beta_{1}$ - as well as $\beta_{2}$-effects, was no difference seen in the dose-response curve between in SHR and WK. The increased pressor effect of isoproterenol as a $P_{2}$ agonist may be eliminated in SHR by its increased depressor effect as a $\beta_{1}$-agonist.

The present experiment showed that the intraventricular injection of a $\beta$-agonist, isoproterenol, in rats caused a central depressor effect, which was neither blocked by a $\beta$ blocker, propranolol, nor by a $\beta_{1}$-blocker, practolol, but was blocked by an $\alpha$-blocker, phentolamine. $\beta_{2}$-agonists, salbutamol and orciprenaline, caused a central pressor response which was blocked by the $\beta$-blocker, propranolol. As the central depressor responses to an $\alpha$-agonist and pressor responses to a $\beta_{z}$-agonist were significantly increased in SHR, our results herein indicate the possible involvement of not only central $\alpha-$, but also $\beta\left(\beta_{2}\right)$ receptors in the hypertensive state.

Acknowledgements: Thanks are duc to Drs. Y. Hamashima and Y. Yamori for pertinent advice and encouragment. 


\title{
REFERENCES
}

1) Yamori, Y., Lovenberg, W. and S.ofrdosu, A.: Science 170, 544 (1970): 2) Yamori, Y., Ooshima, A. ANd OKamoto, K.: Japan. Circulation J. 37, 1235 (1973); 3) Y Amori, Y.: Saishin Igaku. 26, 2063 (1971); (in Japancese) 4) Yavorl, Y., Ooshima, A., Nosaka, S. avd Okamoto, K.: Spontaneous Hypertension. Edited by Okanoto. K. p. 73: Springer-Igaku Shoin, Berlin, New York, Tokyo. (1972): 5) Yamort, Y., di Jove, W., Yamabi, H., Lovlibero, W. ANd SJoerdsma, A.: J. Pharm. Phamacol. 25, 89 (1973): 6) YAmori, Y. Saishin Igaku. 28, 2135 (1973) (in Japanese 7) Nakanura, K., Gerold, M. and Thornf, H.: Arch. Pharmacol. 268, 125 (1971); 8) HeNvieg, M. and Rubenson, A.: I. Pham. Parmacol. 22, 553 (1970); 9) Hennifa, M. ANd Rubenson, A.: I. Phamacol. 23, 407 (1971); 10) Hilise, A. AND Kroneberg, G.: Elurop. J. Pharmacol. 17, 315 (1972); I1) DOBA, N. AND Rils, D.J.: Circulation Res. 32, 584 (1973); 12) Yamori. Y., Yamabe, H., de Jovg, M., Lovf nbtro, W. and Sjolrdsma, A.: Europ. J. Pharmacol. 17, 135 (1972); 13) Hateslfr, G., FinCh, L. AND ThOENen, H.: Experientia 28, 1200 (1972); 14) DaY, M.D. and Roach, A.G. Nature New Biol. 242, 30 (1973); 15) DaY, M.D. AND Roach, A.G.: Brit I. Phamacol. 51, 325 (1974); 16) YAMoru, Y.: Proc. of International Symposium on Hypertension. (1975) (in press); 17) LANDS, A.M., ArNold, A., MCAlliff, J.P., Lutdidna, E.P. ANd Brown, J.G.: Natur 214, 597 (1967)

\section{EFFECT OF 2-(4-BENZYL-PIPERIDINO)-1-(4-HYDROXYPHENYL)- 1-PROPANOL ON ADENYLATE CYCLASE AND 3',5'-CYCLIC AMP PHOSPHODIESTERASE IN VITRO}

\author{
Yoshiaki YAMASHITA, Masami KAWAI and Kei HOTTA \\ General Research Center, Funai Phamaceutical Ca., Lul., \\ Hirakata, Osaka 573, Japan \\ Accepted January 18, 1976
}

It is well established that some vasodilator drugs like the nicotinic acid derivative exert marked effects through relaxation of sascular smooth muscle. Carron ef al. (1) reported the synthesis and pharmacological characteristics of 2-pipcridinoalkanol derivatives, and found 2-(4-benzyl-piperidino)-1-(4-hydroxyphenyl)-1-propanol-1.-(-) artrate (BPHPP) to be a most potent vasodilator. The mechanisms of the pharmacological actions, however, remain unknown. 2-Piperidinoalkanol derivatives also display some prevailing $\alpha$-adrenergic blocking effects; BPHPP has been found to be antagonistic to the epinephrine-induced contractions of the seminal vesicles (1). Since adenylate cyclase is stimulated by epinephrine, glucagon and other hormones (2), and since the biological effects of these hormones are due to the clevation of intracellular cyclic adenosine 3',5'-inonophosphate (cyclic AMP) levels in the target organs (3), studies concerning the participation of BPHPP in the hormone-stimulating adenylate cyclase system are deemed worthy of interest.

During the course of the incstigation of BPHPP on cyclic AMP metabolism, we observed that this agent inhibits both activitics of adenylate cyclase and cyclic AMP phosphodiesterase in ritro.

Male rats of the Wistar strain, weighing from $18010200 \mathrm{~g}$, were maintained on an 